\title{
Evaluation of a Flue Gas Desulphurisation (FGD)-Gypsum from a Wet Limestone FGD as Adsorbent for Removal of Selenium in Water Streams
}

\author{
Patricia Córdoba ${ }^{1,3 *}$, María Eugenia González², Aixa González ${ }^{2}$, Mercedes Maroto-Valer ${ }^{1}$, Natalia Moreno ${ }^{3}$, Noelia Sepúlveda $^{2}$, Rodrigo $^{2}$ \\ Navia $^{2}$ and Xavier Querol ${ }^{3}$
}

${ }^{1}$ Center for Innovation on Carbon Capture and Storage (CCS), Institute of Mechanical, Proccess and Energy Engineering (IMPEE), Heriot-Watt University, Edinburgh, Scotland, EH14 4AS

${ }^{2}$ Department of Chemical Engineering, University of the La Frontera, Castilla 54-D, Temuco, Chile

${ }^{3}$ Institute of Environmental Assessment and Water Research (IDAEA-CSIC), Jordi Girona 18-26, E-08034- Barcelona, Spain

\begin{abstract}
The use of a Flue Gas Desulphurisation (FGD)-gypsum as material for selenium removal in re-circulated waters from a wet limestone FGD system with water re-circulation to the scrubber and with use of an Al-additive, to increase $\mathrm{SO}_{2}$ emission abatement efficiencies, has been evaluated by adsorption studies. Potentiometric titration experiments for FGD-gypsum reveal that the acidic conditions of the aqueous phase of gypsum slurry, induced by the Al-additive, result in the protonation of the FGD-gypsum surface. The adsorption isotherms of Se onto FGD-gypsum are appropriately described by the Langmuir model suggesting that $S e$ is adsorbed by the protons adhered on FGD-gypsum surface and forms a monolayer. The removal of Se from FGD waters by the employment of FGD-gypsum is significant as prevention measure based on the management on FGD-gypsum and water streams before their production and the subsequent disposal in landfills and/or in application scenarios.
\end{abstract}

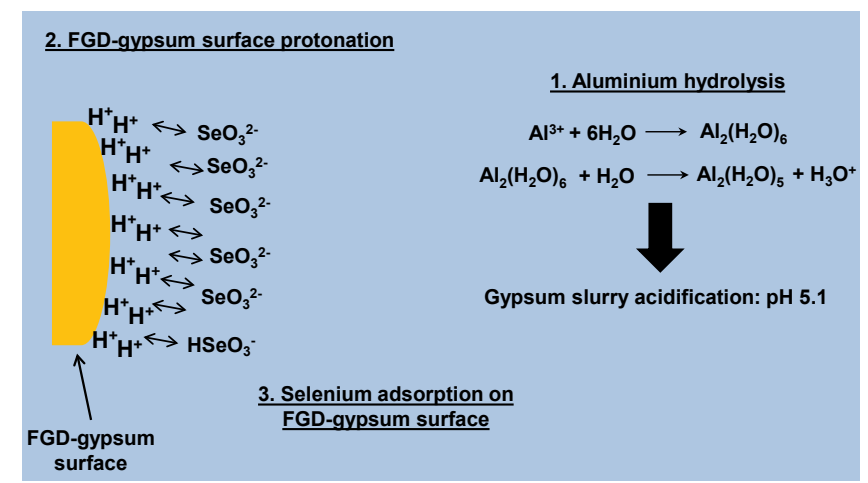

Keywords: FGD-gypsum; Re-circulated waters; FGD systems; Potentiometric titration; Adsorption isotherms

\section{Introduction}

Because coal-combustion processes are well evaluated, general trends in trace element behaviour during combustion have been identified [1-9]. It is common knowledge that many of the trace elements from coal are partially or totally vaporised during combustion. The degree of vaporisation determines how each element is partitioned between various solid residues and the flue gas [1]. Selenium during Pulverised Coal Combustion (PCC) can be released as gas $\mathrm{SeO}_{2}$ and/ or as particulate Se [7-9]. However, when the flue gas cools down some of gas $\mathrm{SeO}_{2}$ may condense on the finest particle surfaces of Fly Ashes (FAs). Most of FAs are captured in cleaning systems by high-efficiency particulate collector devices, though some particulate Se may escape from controls and reach Flue Gas Desulphurisation (FGD) system. Once in $\mathrm{FGD}$, gas $\mathrm{SeO}_{2}$ and particulate Se may be dissolved in the aqueous phase of absorber slurries and/or concentrated in the gypsum sludge [7-9]. Depending on the abatement capacity of FGDs, a given proportion of Se can be released in a gaseous and/or PM form [8,9].

In FGD systems under operational conditions of water recirculation to the scrubber, inorganic trace pollutants initially in subsaturation in FGD waters may reach equilibrium and a subsequent saturation in the water stream after a number of water re-circulations in the scrubber [7]. The gradual increase in the concentration of inorganic trace pollutants from the sub-saturation to equilibrium and/or saturation because of continuous water re-circulation in the scrubber, accounts for enriched inorganic trace pollutants in the recirculated water [7] which could result in environmental (pollution of soil and groundwater) and technical problems (fouling of scrubber and pipes of the FGD), especially, if the re-circulation of the water streams is interrupted and/or a water treatment is necessary for hypothetical and eventual discharges to the environment. High levels of inorganic trace pollutants in re-circulated waters may also reduce the gaseous solubility and probably, the retention efficiencies in wet FGD [7].

*Corresponding author: Patricia Córdoba Sola, Institute of Environmental Assessment and Water Research (IDFEA-CSIC), Jordi Girona 18-26, E-08034- Barcelona, Spain Tel: 44 01314514737; E-mail: pc247@hw.ac.uk or patricia.cordoba@idaea.csic.es

Received June 13, 2015; Accepted June 24, 2015; Published June 28, 2015

Citation: Córdoba P, González ME, González A, Maroto-Valer M, Moreno N, et al. (2015) Evaluation of a Flue Gas Desulphurisation (Fgd)-Gypsum from a Wet Limestone Fgd as Adsorbent for Removal of Selenium in Water Streams. J Environ Anal Toxicol 5: 305. doi:10.4172/2161-0525.1000305

Copyright: (c) 2015 Córdoba $\mathrm{P}$, et al. This is an open-access article distributed under the terms of the Creative Commons Attribution License, which permits unrestricted use, distribution, and reproduction in any medium, provided the original author and source are credited. 
Citation: Córdoba P, González ME, González A, Maroto-Valer M, Moreno N, et al. (2015) Evaluation of a Flue Gas Desulphurisation (Fgd)-Gypsum from a Wet Limestone Fgd as Adsorbent for Removal of Selenium in Water Streams. J Environ Anal Toxicol 5: 305. doi:10.4172/21610525.1000305

The evaluation of desulphurisation efficiency and abatement capacity of inorganic trace pollutants at a coal-fired power plant equipped with a wet limestone FGD system with water re-circulation to the scrubber [7], revealed that the emission of non-retained FA by FGD and the particles and droplets from gypsum slurry entrained by the outgoing flue gas stream (OUT-FGD) were the most important consequence of the high enrichment of elements of environmental concern, such as $\mathrm{Al}, \mathrm{F}, \mathrm{Cl}, \mathrm{B}, \mathrm{U}, \mathrm{Hg}$, and especially Se, in the re-circulated water, being selenite $\left(\mathrm{SeO}_{3}{ }^{2-}\right)$ the main aqueous complex of $\mathrm{Se}$ in the enriched water stream from this power plant [10].

Selenite $\left(\mathrm{SeO}_{3}{ }^{2-}\right)$ and selenate $\left(\mathrm{SeO}_{4}^{2-}\right)$ are generally removed by conventional wastewater treatments such as coagulation-sedimentation and biological and/or chemical reduction processes [11-13]. Nevertheless, these processes are not currently carried out in coalfired power plants owing to the expensive cost of maintenance and the discharges of large amount of sludge [14]. The adsorption of $\mathrm{SeO}_{4}{ }^{2-}$ and $\mathrm{SeO}_{3}{ }^{2-}$ has also been extensively studied [15-20]. However, all these studies have been focused on adsorption processes by conventional adsorbents such as hydrous ferric oxide, goethite, gibbsite, activated carbon, etc.

With the advent of increasingly restrictive regulations on air, water, and soil quality and the growing concern about health effects of exposure to heavy metals even at trace levels, the employment of FGD-gypsum for the Se adsorption from FGD water streams could be tested as prevention measure based on the management on solid (FGD-gypsum) and water (aqueous phase of gypsum slurry) streams before their production and the subsequent disposal in landfills and/ or in application scenarios. In this work, a FGD-gypsum from a coalfired power plant equipped with a wet limestone FGD-system has been evaluated as adsorbent for the removal of $\mathrm{SeO}_{3}{ }^{2-}$ in water streams on the basis that the acidification of the aqueous phase of gypsum slurry, induced by the use of the Al-additive (sulphate) [10,21], led to the protonation of its surface, which could give rise to adsorption of Seaqueous complexes.

\section{Materials and Methods}

\section{The FGD-gypsum}

The FGD-gypsum used as an adsorbent in this study stems from a wet limestone FGD-system that operates with a forced oxidation system and re-circulation of water from gypsum slurry filtration to the scrubber. This FGD system includes a number of water streams categorised as FGD water streams: limestone and gypsum slurries, and filtered water. Limestone slurry is prepared with process water and is introduced into the scrubber. Gypsum slurry is the result of the desulphurisation process; whereas filtered water is the water stream that results after filtration and subsequent dilution of the aqueous phase of gypsum slurry. Filtered water is directly re-circulated to the scrubber after the dilution process. This result in limestone slurry water/filtered water mixture ratio of $0.47 / 0.53$ into the scrubber.

The Al-additive $\left(\mathrm{Al}_{2}\left(\mathrm{SO}_{4}\right)_{3}\right)$ is added to boost the efficiency of the desulphurisation process as a consequence of the low porosity of limestone. The addition of $\mathrm{Al}_{2}\left(\mathrm{SO}_{4}\right)_{3}$ promotes the interaction between $\mathrm{Al}$ and $\mathrm{F}$ increasing the capacity of limestone for $\mathrm{SO}_{2(\mathrm{~g})}$ retention and preventing the formation of $\mathrm{CaF}_{2}$ particles. However, it has been demonstrated [21] that the addition of $\mathrm{Al}_{2}\left(\mathrm{SO}_{4}\right)_{3}$ to the scrubber also causes the acidification of the aqueous phase of gypsum slurry via aluminium hydrolysis. A sketch of the FGD system at the coal-fired power plant is shown in Figure 1. Detailed descriptions of the operation

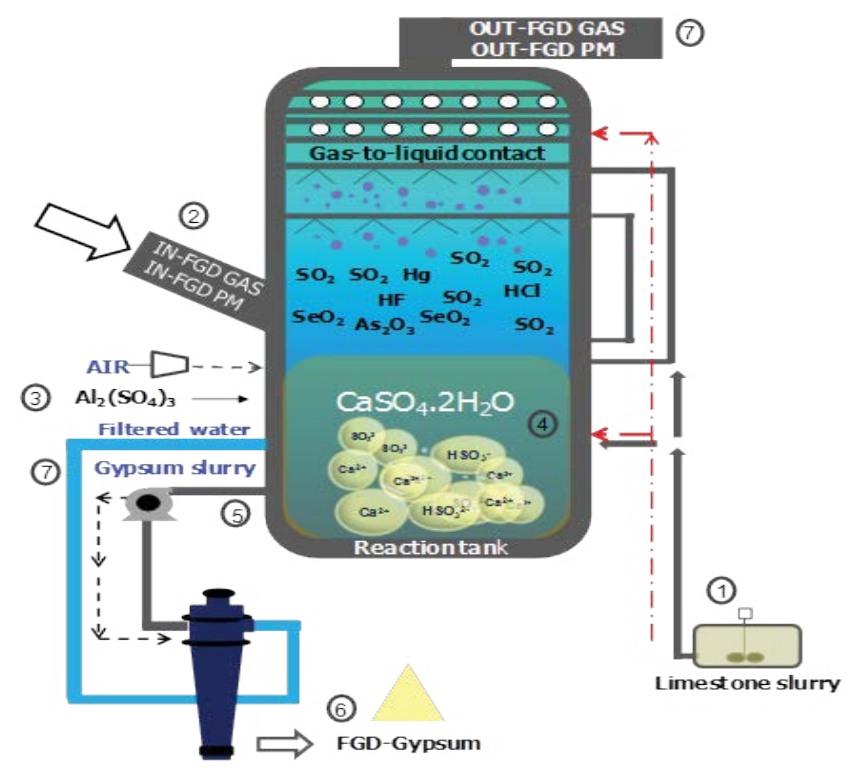

Figure 1: Flue Gas Desulphurisation system.

1. Limestone slurry introduced and sprayed into the scrubber to react with $\mathrm{SO}_{2}$.

2. Gas and PM input flow into the scrubber after combustion process

3. Addition of $\mathrm{Al}_{2}\left(\mathrm{SO}_{4}\right)_{3}$

4. Formation of gypsum slurry as result of the desulphurisation process.

5. Filtration of gypsum slurry by hydro-cyclones=gypsum slurry water and gypsum production.

6. Re-circulation of filter water directly to the scrubber.

7. Cleaned gas and PM flow OUT-FGD.

of the FGD system at the coal-fired power plant and the water streams are provided $[7,9]$.

The sampling collection was carried out at 100\% MCR (Maximum Capacity Rate) of the power plant and $100 \%$ desulphurisation on two consecutive days. A sampling per day during two days was performed for each sample collecting two sample sets. FGD-gypsum samples once mixed, homogenised, and riffled, were divided into subsamples of 5 $\mathrm{kg}$. FGD-gypsum samples of $1 \mathrm{~kg}$ were dried at $45^{\circ} \mathrm{C}$ to avoid loss of crystallisation water of gypsum for the analysis of major, minor, and trace elements. These FGD-gypsum samples were used to carry out the present study.

\section{Characterisation of FGD-gypsum}

Physical analysis: The specific surface area and the volume and distribution of pores of FGD-gypsum were determined to evaluate FGDgypsum as adsorbent material. These parameters were measured using a gravimetric method based on the adsorption of $\mathrm{N}_{2}$ and at constant temperature with Quantachrome Nova Wing 2. These experiments were carried out in the Department of Chemical Engineering at the University of the La Frontera, Temuco, Chile.

Variation of FGD-gypsum surface with $\mathbf{p H}$ : The variation of FGD-gypsum surface with $\mathrm{pH}$ was performed to ascertain whether the acidic aqueous phase ( $\mathrm{pH}$ 5.1) of gypsum slurry may lead to the protonation of FGD-gypsum surface.

Surface charge behaviour of FGD gypsums was evaluated by acidbase titration at the initial $\mathrm{pH}$ of the FGD-gypsum to measure the adsorption/desorption of $\mathrm{H}^{+}$as a function of $\mathrm{pH}$, ionic strength $(0.01$, 0.1 , and $1 \mathrm{M} \mathrm{KCl})$, and temperature $\left(25^{\circ} \mathrm{C}\right)$. The system consisted in a $\mathrm{pH}-$ meter with two connected pipettes, one for the acidic solution $(0.02 \mathrm{~N}$ 
Citation: Córdoba P, González ME, González A, Maroto-Valer M, Moreno N, et al. (2015) Evaluation of a Flue Gas Desulphurisation (Fgd)-Gypsum from a Wet Limestone Fgd as Adsorbent for Removal of Selenium in Water Streams. J Environ Anal Toxicol 5: 305. doi:10.4172/21610525.1000305

Page 3 of 6

$\mathrm{HCl})$ and the other for the basic one $(0.02 \mathrm{~N} \mathrm{NaOH})$. FGD-gypsum $(0.3 \mathrm{~g})$ was placed in a vessel isolated from any external perturbance with four pull-tabs for the acid-base addition; the temperature and $\mathrm{pH}$ control, and for a $\mathrm{N}_{2}$ stream inclusion to eliminate atmospheric $\mathrm{CO}_{2}$. Once the $\mathrm{pH}$ of FGD-gypsum suspension was stabilized, the acid/base additions were set up in a range time from one to five minutes until a constant $\mathrm{pH}[22]$. The time spent for each potentiometric titration experiment was around 60 minutes.

\section{Adsorption studies}

Material: A stock anion solution of $\mathrm{SeO}_{3}^{2-}$ was prepared with $\mathrm{Na}_{2} \mathrm{SeO}_{3}$ for the adsorption experiments in order to assess the effectiveness treatment and management for the removal of Se based on adsorption processes by FGD-gypsum. $\mathrm{Na}_{2} \mathrm{SeO}_{3}$ of analytical grade ( $>95 \%)$ was supplied by Sigma Aldrich and used in the experimental tests.

Kinetic study: Kinetic experiments were carried out to determine the influence of the time required for the attainment of equilibrium during the adsorption process. The adsorption kinetics was conducted in $100 \mathrm{~mL}$ amber bottles previously treated with TOC (Total Organic Carbon) water and $\mathrm{HNO}_{3}$. Total volumes of $40 \mathrm{~mL} \mathrm{Na}_{2} \mathrm{SeO}_{3}$ solution $(\mathrm{Co}=10 \mathrm{mg} / \mathrm{L})$ were mixed with the FGD-gypsum $(1.0 \mathrm{~g})$ at a $1 / 40$ solid-to-liquid (S/L) ratios. The FGD-gypsum/ $/ \mathrm{Na}_{2} \mathrm{SeO}_{3}$ solutions at $\mathrm{pH}$ 7.6 were initially shaken for $1,3,5,15,30,45 \mathrm{~min}$; and subsequently for $1,2,4,6,8,10,12,24$, and $48 \mathrm{~h}$ at a rate of $120 \mathrm{rpm}$, using the MAXQ 6000 shaker from Thermo Fisher SCIENTIFIC, at constant temperature $\left(30^{\circ} \mathrm{C}\right)$. The temperature was set up according to the temperature of the gypsum slurry filtration process which occurs at about $30^{\circ} \mathrm{C}$. In wet limestone FGD systems, which usually operate at around $60^{\circ} \mathrm{C}$, gypsum slurry comes out the FGD at about $40^{\circ} \mathrm{C}$; subsequently, it follows a filtration process which gives rise to filtered water and FGD-gypsum. During the filtration process the gypsum slurry is cooled down at about $30^{\circ} \mathrm{C}$, temperature at which removal treatments for metals are applied. Three FGD-gypsum replicates were prepared in a similar manner and mean values are presented.

The samples were then filtered at vacuum through a membrane filter of $0.45 \mu \mathrm{m}$. The concentration of $\mathrm{Na}_{2} \mathrm{SeO}_{3}$ in the supernatant solution was measured by Atomic Absorption Spectroscopy coupled with Hydrides Generation (HGAAS).

Adsorption isotherms: $\mathrm{Na}_{2} \mathrm{SeO}_{3}$ adsorption isotherms were determined under the same experimental conditions as for adsorption kinetics. $\mathrm{Na}_{2} \mathrm{SeO}_{3}$ solutions were prepared at concentrations of 5,10 , and $20 \mathrm{mg} / \mathrm{L}$. Langmuir model was found to fit with the experimental data. The Langmuir model assumes that a monomolecular layer is formed when adsorption takes place without any interaction between the adsorbed molecules [23]. The Langmuir model can be represented as:

$$
\frac{X}{M}=\frac{K b C_{e}}{1+K C_{e}}
$$

Where $\mathrm{X} / \mathrm{M}$ is the amount of solute retained per unit weight of the adsorbent, $\mathrm{K}$ is a constant related to the affinity of the binding sites $(\mathrm{mg} / \mathrm{L})$, Ce is the equilibrium concentration in solution $(\mathrm{mg} / \mathrm{L})$, $\mathrm{b}$ represents the maximum amount that can be adsorbed $(\mathrm{mg} / \mathrm{g}), \mathrm{b}$ is $\mathrm{M}$ for a complete monolayer $(\mathrm{mg} / \mathrm{g})$. The rearranged expression of Equation 1 used to obtain its most suitable linear form is:

$$
\frac{C e}{X / M}=\frac{1}{K b}+\frac{C e}{b}
$$

\section{Selenium adsorption on FGD-gypsum}

Identification of mineral and solid phases on FGD-gypsums: The mineralogy of FGD-gypsum was determined by X-ray powder diffraction (XRD) with a Bruker D5005 diffractometer with monochromatic $\mathrm{Cu} \mathrm{Ka1,2}$ radiation operated at $40 \mathrm{KV}$ and $40 \mathrm{~mA}$, from 4 at $60^{\circ}$ of theta range, and a step size of $0.05^{\circ}$ and $3 \mathrm{~s} / \mathrm{step}$.

The identification of Se solid phases on FGD-gypsum was carried out by Time-of-Flight Secondary Ion Mass Spectrometry (ToF-SIMS). ToF-SIMS is a method of mass spectrometry in which the FGD-gypsum sample is ionised and accelerated by an electric field of a given strength. Since the velocity of the ion depends on the mass-to-charge ratio, the ions acquire the same kinetic energy of other ions with the same charge. The time spent by ions reaching the detector and the experimental parameters allow us to identify the ion mass with great accuracy. Thus, the identification of molecules and ionic clusters such as selenates, silicates, sulphates, hydroxides, nitrates, and borates that precipitated on FGD-gypsums may be detected even at low concentrations.

The ToF-SIMS analyses were performed using a ToF-SIMS IV (ION-ToF, Munster, Germany) operated at a pressure of $5 \times 10^{-9} \mathrm{mbar}$. Samples were bombarded with a pulsed Bismuth liquid metal ion source $\left(\mathrm{Bi}_{3}^{++}\right)$, at energy of $25 \mathrm{keV}$. The gun was operated with a $20 \mathrm{~ns}$ pulse width, $0.3 \mathrm{pA}$ pulsed ion current for a dosage lower than $5 \times 10^{11}$ ions $/ \mathrm{cm}^{2}$, well below the threshold level of $1 \times 10^{13}$ ions $/ \mathrm{cm}^{2}$ generally accepted for static SIMS conditions. Secondary ions were detected with a reflector time-of-flight analyzer, a multichannel plate (MCPs), and a time-to-digital converter (TDC). Measurements were performed with a typical acquisition time of $6 \mathrm{~s}$, at a TDC time resolution of $200 \mathrm{ps}$ and $100 \mu$ s cycle time. Charge neutralization was achieved with a low energy $(20 \mathrm{eV})$ electron flood gun. Secondary ion spectra were acquired from a randomly rastered surface areas of $50 \mu \mathrm{m} \times 50 \mu \mathrm{m}$ within the sample's surface. Secondary ions were extracted with $2 \mathrm{kV}$ voltages and are post accelerated to $10 \mathrm{keV}$ kinetic energy just before hitting the detector. Mass spectral acquisition was performed within the ION-TOF Ion Spec software (version 4.1). Each spectrum was normalised to the total intensity.

\section{Results and Discussion}

\section{FGD-gypsum characterisation}

FGD-gypsum presents a relatively small specific surface area $(9.51$ $\mathrm{m}^{2} / \mathrm{g}$ ) in comparison with conventional adsorbents materials such as alumina, bauxite, and activated carbon, which usually present superficial surface areas higher than $200 \mathrm{~m}^{2} / \mathrm{g}$. However, the protonation of its surface induced by the acidic conditions of the gypsum slurry aqueous phase may lead to a significant high electrostatic attraction between the positively charged surface of the FGD-gypsum and the anionic Se forming a monolayer. Physical properties of FGD-gypsum samples are depicted in Table 1.

\begin{tabular}{|c|c|c|c|c|c|}
\hline \multicolumn{5}{|c|}{ FGD-gypsum } \\
\hline & Pore diameter $(\AA)$ & Pore volume $(\mathrm{cc} / \mathrm{g})$ & Surface area $\left(\mathrm{m}^{2} / \mathrm{g}\right)$ & Particle size $(\mu \mathrm{m})$ \\
\hline FGD-gypsum & 39.39 & 0.02 & 9.41 & 47 \\
\hline
\end{tabular}


Citation: Córdoba P, González ME, González A, Maroto-Valer M, Moreno N, et al. (2015) Evaluation of a Flue Gas Desulphurisation (Fgd)-Gypsum from a Wet Limestone Fgd as Adsorbent for Removal of Selenium in Water Streams. J Environ Anal Toxicol 5: 305. doi:10.4172/21610525.1000305

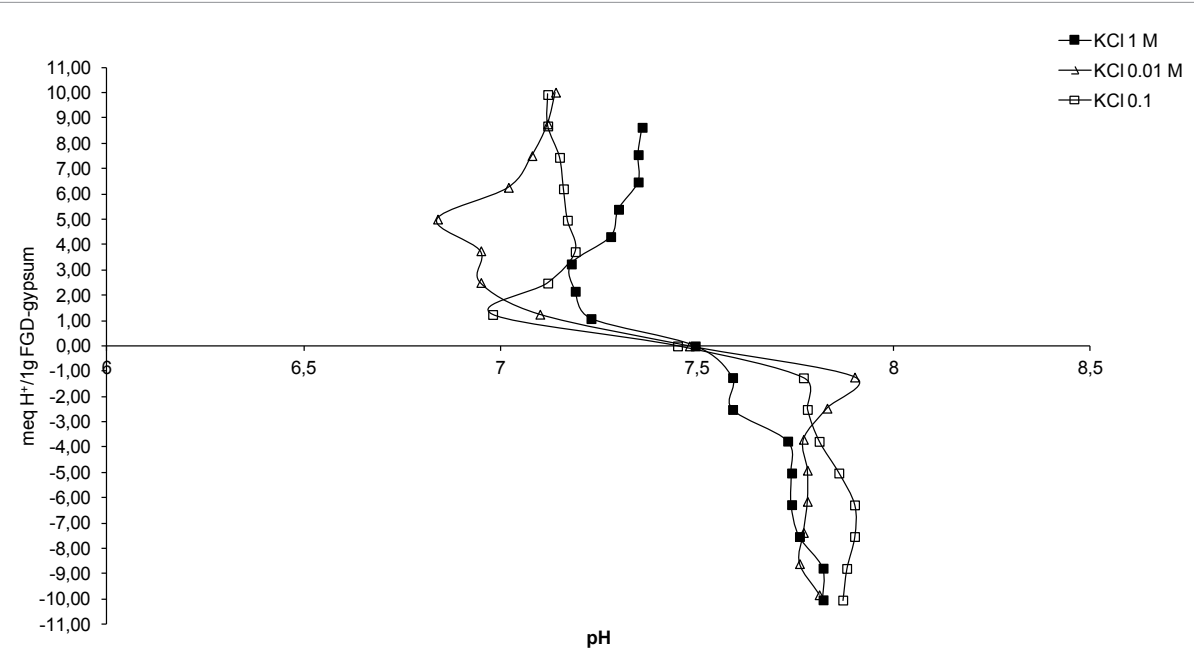

Figure 2: Potentiometric profiles of FGD-gypsum.

\section{FGD-gypsum surface protonation}

The pzc of the FGD-gypsum as a function of the ionic strengths $(0.01,0.1$, and $1 \mathrm{M} \mathrm{KCl})$ and temperature $\left(25^{\circ} \mathrm{C}\right)$ is 7.5 (Figure 2). The shape of the potentiometric curves points out that at $\mathrm{pH}$ lower than 7.5 the FGD-gypsum surface is positively charged (Figure 2 ). When the $\mathrm{pH}$ is lower than the pzc value, acidic water donates more $\mathrm{H}^{+}$than $\mathrm{OH}^{-}$, and therefore the adsorbent surface is positively charged (attracting anions). Conversely, above pzc the surface is negatively charged (attracting cations/repelling anions). Therefore, the acidic conditions of gypsum slurry aqueous phase ( $\mathrm{pH}$ 5.1) [9] induced by the addition of $\mathrm{Al}_{2}\left(\mathrm{SO}_{4}\right)_{3}$, led to the protonation of the FGD-gypsum surface.

\section{Adsorption kinetics}

In this article, the effect of the contact time on the $\mathrm{SeO}_{3}{ }_{3}^{2-}$ adsorption kinetic on FGD-gypsum is discussed from the beginning of the adsorption experiment until the first 120 minutes as $\mathrm{SeO}_{3}{ }^{2-}$ adsorption reaches equilibrium at that time and does not experiment a larger adsorption over time Figure 3.

In $\mathrm{SeO}_{3}{ }^{2-}$ adsorption kinetics on FGD-gypsums (Figure 3), three phases can be observed. A first phase is characterised by a dynamic and gradual adsorption up to the first 40 minutes with a maximum adsorption close to the 30 minutes of the adsorption kinetic process. The second phase is characterised by desorption from 30 to 45 minutes, which could be due to a possible saturation of the FGD-gypsum surface and/or impurities retained on the FGD-gypsum leading to desorption of $\mathrm{SeO}_{3}^{2-}$ from the FGD-gypsum surface to the aqueous phase. It is important to point out that $\mathrm{SeO}_{3}{ }^{2-}$ desorption could be due to possible competition for the active sites of the FGD-gypsum surface as ionic groups such as $\mathrm{SO}_{3}, \mathrm{SO}_{4}$, and $\mathrm{HSO}_{4}$; monatomic ions of $\mathrm{O}$, and polyatomic such as $\mathrm{OH}$ have also been identified in this in FGDgypsum [10]. The third phase is characterised by a second adsorption from 45 to 120 minutes. The second adsorption of $\mathrm{SeO}_{3}{ }^{2-}$ on the FGDgypsum describes a progressive adsorption pattern and reaches the equilibrium in about 120 minutes; no higher adsorption after the 120 minutes was observed. Further increase of contact time cannot lead to stronger adsorption capacity.

\section{Modelling of adsorption isotherms}

The experimental data correlates with the lineal Langmuir

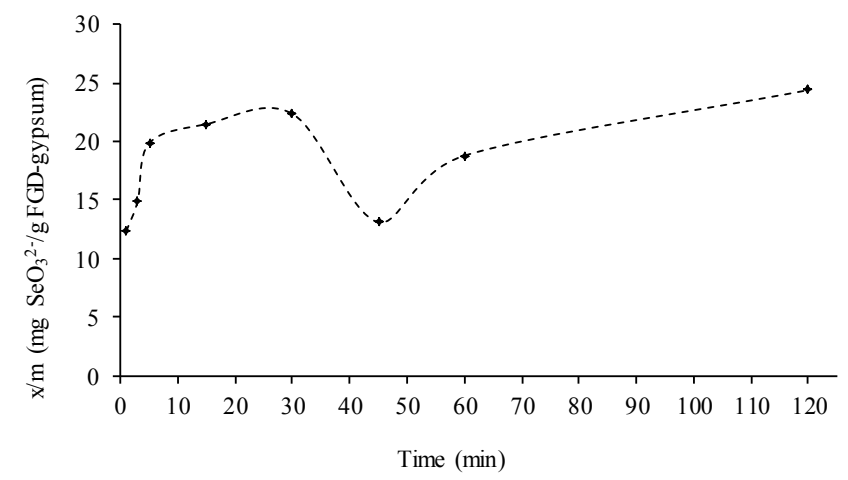

Figure 3: Selenium adsorption kinetics on FGD-gypsum.

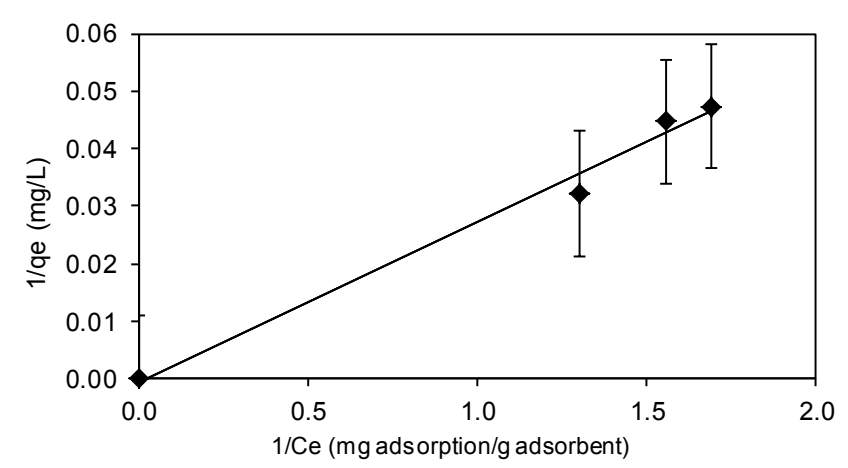

Figure 4: Selenium adsorption isotherms.

\begin{tabular}{|l|c|c|c|}
\hline \multirow{2}{*}{ FGD-gypsum } & \multicolumn{3}{|c|}{ Langmiur constants } \\
\cline { 2 - 4 } & $\mathrm{Q}_{\max (m / g)}$ & $\mathrm{K}_{(\mathrm{L} / \mathrm{mg})}$ & $\mathrm{R}^{2}$ \\
\hline
\end{tabular}

Table 2: Langmiur constants of $\mathrm{SeO}_{3}{ }^{2-}$ adsorption on FGD-gypsum.

adsorption isotherms in FGD-gypsum which reveal the applicability of this isotherm on the ongoing adsorption process (Figure 4). Langmuir $(\mathrm{K}$ and $\mathrm{b})$ isotherm parameters as well as regression coefficient $\left(\mathrm{R}^{2}\right)$ are presented in Table 2. 
Citation: Córdoba P, González ME, González A, Maroto-Valer M, Moreno N, et al. (2015) Evaluation of a Flue Gas Desulphurisation (Fgd)-Gypsum from a Wet Limestone Fgd as Adsorbent for Removal of Selenium in Water Streams. J Environ Anal Toxicol 5: 305. doi:10.4172/21610525.1000305
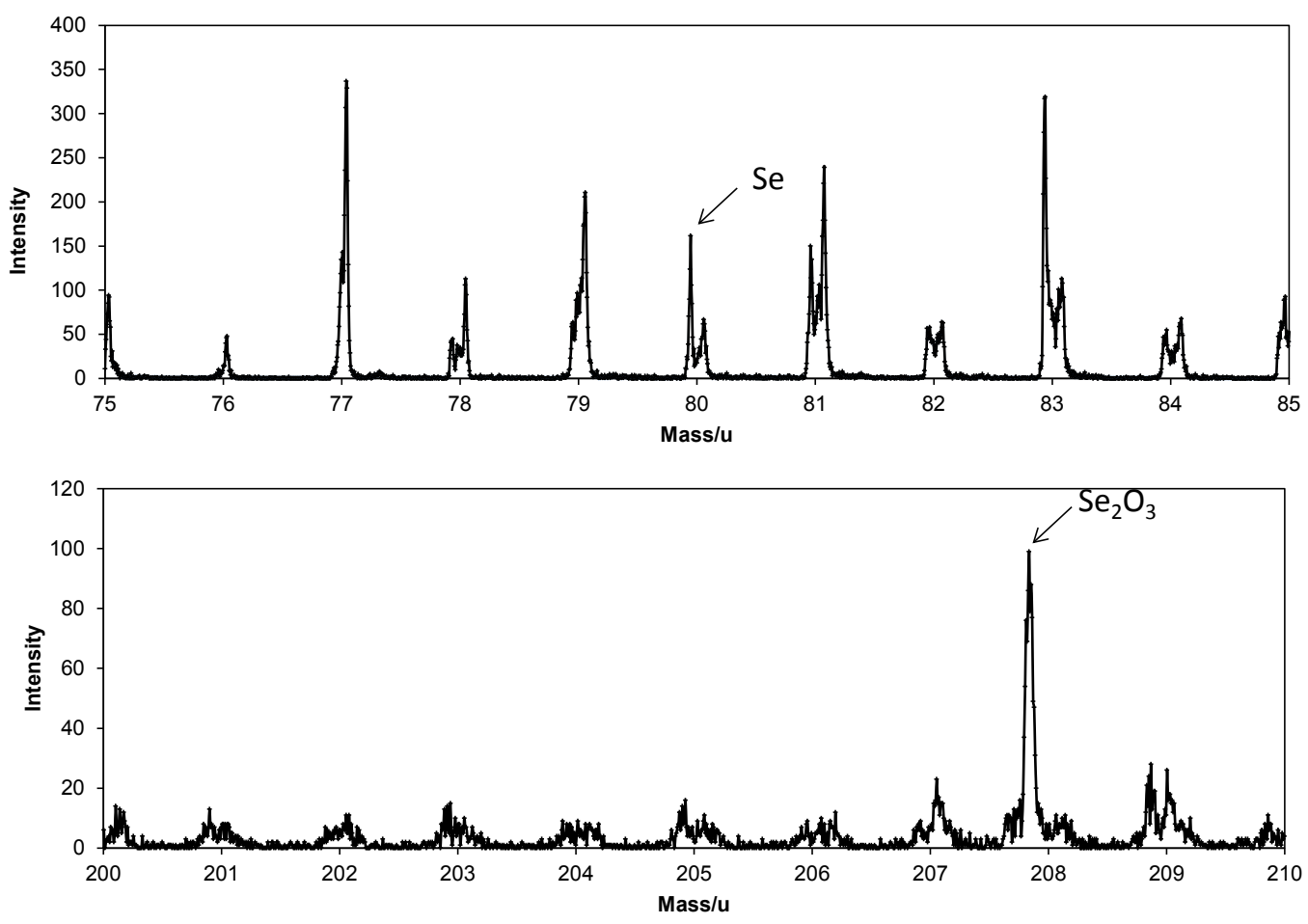

Figure 5: Identification of $\mathrm{SeO}_{3}^{2-}$ on FGD-gypsum by TOF-SIMS.

This model effectively describes adsorption of $\mathrm{SeO}_{3}{ }^{2-}$ on $\mathrm{FGD}$ gypsum with $\mathrm{R}^{2}$ value $>0.97$. The $\mathrm{SeO}_{3}{ }^{2-}$ maximum adsorption capacity of FGD-gypsum was determined to be $31 \mathrm{mg} / \mathrm{g}$ for an adsorbent/ solution ratio of $1 / 40$ at $25^{\circ} \mathrm{C}$ and a $\mathrm{K}$ value of 35.84 . The correlation of Langmuir adsorption isotherm within the studied temperature suggests that $\mathrm{Se}$ is adsorbed by the protons adhered on FGD-gypsum surface and forms a monolayer.

According to Mittal [24], the successive steps involved in the adsorption of an organic/inorganic compound by an adsorbent are: i) transport of the ions (adsorbate) to the external surface of the adsorbent (film diffusion); ii) transport of the adsorbates within the pores of the adsorbent except for a small amount of adsorption, which occurs on the external surface (particle diffusion); and iii) adsorption of the ion (adsorbate) on the interior surface of the adsorbent. The transport and adsorption of $\mathrm{SeO}_{3}^{2-}$ ions into the external surface of the adsorbent, FGD-gypsum, can be considered the main mechanism of the Se adsorption on FGD-gypsum.

\section{Identification of mineral and solid phases on FGD-gypsum}

Major solid phases $\mathrm{CaSO}_{4} \cdot 2 \mathrm{H}_{2} \mathrm{O}$ and $\mathrm{CaCO}_{3}$ and traces of $\mathrm{CaAl}_{2} \mathrm{Si}_{3} \mathrm{O}_{10} \cdot 6 \mathrm{H}_{2} \mathrm{O}$ were identified in the FGD-gypsum by XRD. Mass spectrometry analysis (Figure 5 ) by TOF detected Se and ionic groups $\mathrm{Se}_{2} \mathrm{O}_{3}$ in FGD-gypsum.

Identification of the intensity signal of $\mathrm{Se}$ and $\mathrm{Se}_{2} \mathrm{O}_{3}$ in FGDgypsum (Figure 5) revealed that $\mathrm{SeO}_{3}$ is adsorbed by FGD-gypsum on its surface. Therefore, it may be concluded that the acidic conditions of the aqueous phase of gypsum slurry led to the protonation of the gypsum surface. The significantly high electrostatic attraction existing between the positively charged surface of the FGD-gypsum and the anionic Se promotes de adsorption of this element on its surface forming a monolayer. Figure 5 shows the Se adsorption mechanism on the FGD-gypsum surface.

\section{Conclusions}

The study reported here demonstrates that the FGD-gypsum could be considered an effectual and viable adsorbent to remove Se in FGD waters. The different operational parameters observed during the process of investigations reveal that the protonation of the FGDgypsum surface is the cause of Se retention on FGD-gypsum. The potentiometric results indicate that the FGD-gypsum is positively charged as a consequence of the acidification of the gypsum slurry aqueous phase, induced by the addition of $\mathrm{Al}_{2}\left(\mathrm{SO}_{4}\right)_{3}$ to the scrubber, via aluminium hydrolysis.

The adsorption isotherms of Se onto FGD-gypsum are appropriately described by the Langmuir model suggesting that Se is adsorbed by the protons adhered on FGD-gypsum surface and forms a monolayer.

TOF mass spectrometry results demonstrate the adsorption of Se on FGD-gypsum.

The removal of Se from FGD waters by the employment of FGDgypsum is significant as prevention measure based on the management on solid (FGD gypsum) and water (aqueous phase of gypsum slurry) streams before their production and the subsequent disposal in landfills and/or in application scenarios.

\section{Acknowledgement}

We would like to thank the staff of the Spanish power plants for their support, help, and kind assistance during and after the collection of the samples. The corresponding author gratefully acknowledges the Department of Chemical Engineering, University of the La Frontera (Temuco, Chile) and Institute of Environmental Assessment and Water Research (IDAEA). Spanish Research Council (CSIC). 
Citation: Córdoba P, González ME, González A, Maroto-Valer M, Moreno N, et al. (2015) Evaluation of a Flue Gas Desulphurisation (Fgd)-Gypsum from a Wet Limestone Fgd as Adsorbent for Removal of Selenium in Water Streams. J Environ Anal Toxicol 5: 305. doi:10.4172/21610525.1000305

Page 6 of 6

\section{References}

1. Clarke L, Sloss L (1992) Trace elements. EIACR/49.Ed, IEA Coal research, pp. 51

2. Meij R (1994) Trace element behaviour in coal-fired power plants. Fuel Process Technol 39: 199-217.

3. Aunela-Tapola L, Hatanpää E, Hoffren H, Laitinen T, Larjava K, et al.(1998) A study of trace element behaviour in two modern coal-fired power plants: II. Trace element balances in two plants equipped with semi-dry flue gas desulphurisation facilities. Fuel Proces Tech 55: 13-34.

4. Heebink LV, Hassett DJ (2003) Hg release from FGD. In proceeding of International Ash Utilization Symposium, CAER, University of Kentucky. Pp. 75.

5. Schroeder K, Kairies C (2005) Distribution of Hg in FGD by-products. In Proceedings of World of Coal Ash Conference, CAER, University of Kentucky. Pp. 100.

6. Álvarez-Ayuso E, Querol X, Tomás A (2006) Environmental impact of coal combustion-desulphurisation plant: Abatement capacity of desulphurisation process and environmental characterisation of combustion by-products. Chemosphere 665: 2009-2017.

7. Córdoba P, Font O, Izquierdo M, Querol X, Tobías A, et al. (2011) Enrichment of inorganic trace pollutants in re-circulated water streams from a wet limestone flue gas desulphurisation system in two coal power plants. Fuel Process Technol 92: 1764-1775.

8. Córdoba P, Font O, Izquierdo M, Querol X, Leiva C, et al. (2012a) The retention capacity for trace elements by the flue gas desulphurisation system under operational conditions of a co-combustion power plant. Fuel 102: 773-78.

9. Córdoba P, Ochoa-González R, Font O, Izquierdo M, Querol X, et al. (2012b) Partitioning of trace inorganic elements in a coal-fired power plant equipped with a wet flue gas desulphurisation system. Fuel 92: 145-157.

10. Córdoba P, Ayora C, Moreno N, Font O, Izquierdo M, et al. (2013) Influence of an aluminium additive in aqueous and solid speciation of elements in flue gas desulphurisation (FGD) system. Energy 50: 438-444.

11. Hingston FJ, Atkinson RJ, Posner AM, Quirk JP (1967) Specific adsorption of anions. Nature 215: 1459-1461.
12. Hingston FJ, Posner AM, Quirk JP (1986) Adsorption of selenite by goethite. Adv Chem Ser 70: 82-90.

13. Murphy AP (1988) Removal of Selenate from water by chemical reduction. Ind Eng Chem Res 27: 187-191.

14. Akiho $\mathrm{H}$, Ito $\mathrm{S}$, Matsuda $\mathrm{H}$ (2010) Effect of oxidizing agents on selenate formation in a wet FGD. Fuel 89: 2490-2495

15. Roy WR, Hasset JJ, Griffin RA (1986) Competitive coefficients for the adsorption of arsenate, molybdate, and phosphate mixtures by soils. Soil Sci Soc Am J 50: 1176-1182.

16. Hawke D, Carpenter PD, Hunter KA (1989) Competitive adsorption of phosphate on goethite in marine electrolytes. Environ Sci Technol 23: 187-191.

17. Zhang PC, Sparks DL (1989) Kinetics and mechanisms of molybdate asorption desorption at the goethite/water interface using pressure-jump relaxation. Soil Sci Soc Am J 54: 1266-1273.

18. Bolan NS, Syers JK, Summer ME (1993) Calcium-induced sulphate adsorption by soil. Soil Sci Am J 57: 691-696.

19. Wilkie JA, Hering JG (1996) Adsorption of arsenic onto hydrous ferric oxide: effects of adsorbate/adsorbent ratios and co-occurring solutes. Colloids Surf 107: $97-110$.

20. Wu CH, Lo SL, Lin CF, Kuo CY (2001) Modeling Competitive Adsorption of Molybdate, Sulfate, and Selenate on gamma-Al(2)O(3) by the Triple-Layer Model. J Colloid Interface Sci 233: 259-264.

21. Ochoa-González R, Díaz-Somoano M, López Antón MA, Martínez-Tarazona MR (2012) Effect of adding aluminum salts to wet FGD systems upon the stabilization of mercury. Fuel 96: 568-571.

22. Sposito G, Holztclaw KM (1977) Titration Studies on the Polynuclear, Polyacidic Nature of Fulvic Acid Extracted from Sewage Sludge-soil Mixtures. Soil Sci Society of American Journal 41: 330-33.

23. Aksu Z (2002) Determination of the equilibrium, kinetic and thermodynamic parameters of the batch biosorption of nickel (II) ions onto Chlorella vulgaris. Process Biochem 38: 89-99.

24. Mittal A, Kurup L, Mittal J (2007) Freundlich and Langmuir adsorption isotherms and kinetics for the removal of Tartrazine from aqueous solutions using hen feathers. J Hazard Mater 146: 243-248. 